\title{
ETHNOBOTANY OF MEDICINAL PLANTS AND TRADITIONAL RITUALS COMMUNITY OF SEMBALUN VILLAGE, EAST LOMBOK
}

\author{
Hidayani $^{1}$, Gito Hadiprayitno ${ }^{1}$, Kusmiyati ${ }^{1}$, and Jono Irawan ${ }^{2}$ \\ ${ }^{1}$ Biology Education Department, FKIP University of Mataram, Mataram, Indonesia \\ ${ }^{2}$ Magister of Science Education Department, University of Mataram, Mataram, Indonesia \\ Email: hidhayhani06@gmail.com
}

Acceped: October, 31 2021. Approved: November, 24 2021. Published: November, 252021

\begin{abstract}
The use of plant species by the community is an inseparable unit in everyday life. The use of plants used by the community in Sembalun Village for medicines and traditional rituals has been attached and is a hereditary tradition. Community knowledge about the use of plants for treatments and traditional rituals has not been well documented. This study aimed to determine the species of medicinal plants and traditional rituals and find out the parts of plants used by the community in Sembalun Village. This type of research is descriptive qualitative through direct observation, and interviews were conducted on 33 respondents using descriptive methods and purposive sampling techniques. The results showed that 58 species of medicinal plants from 30 families and 5 species of plants for traditional rituals from 5 families were used by the people of Sembalun Village. These medicinal plant species are believed to cure 28 types of diseases. They are used in the traditional rituals of Sembe, Ngeayu-ayu, Bebije Tawar, and Soyot (Sapindus rarak) in washing traditional Bale Lokak clothes. The most widely used plant parts were leaves of as many as 21 species, and the least used were seeds and flowers as many as 1 species plant.
\end{abstract}

Keywords: Ethnobotany, medicinal plants, traditional rituals, Sembalun Village

\section{INTRODUCTION}

Ethnobotany is a science that studies the relationship between humans and plants. Ethnobotany describes and explains the link between culture and the use of plants, how plants are used, cared for, and judged to benefit humans, one of which is plants used for medicines and to support traditional rituals by the community. It is because Indonesia's biodiversity is very abundant. Indonesia's area is around $1.3 \%$ of the surface of Planet Earth, making Indonesia a "megabiodiversity" country [1-2]. Indonesia is very rich in various types of plants. There are approximately 30 thousand species of the 40 thousand species of plants that exist in the world. Around 26\% have been cultivated, and about $74 \%$ are still growing wild in the forest [3].

Indonesia is a multicultural country. Almost all regions in Indonesia have a variety of cultures that are different from one another. Lombok Island among its residents is better known and more popularly known as Gumi Sasak or Gumi Selaparang, precisely in the Sembalun Village area, Sembalun District, which has the potential for biodiversity in the form of plants. Communities in the area have a culture that still has the value of traditional wisdom and traditions. The tradition is passed down from generation to generation is still preserved in the use of plants by looking at the potential of plants in the area and the culture of the people around the area.

The Sembalun Village area, Sembalun District, has the potential for biodiversity in the form of plants. The community in the area has a culture that still has the value of traditional wisdom in using plants by looking for potential plants and the culture of plants use.

Public knowledge about plants as an ethnobotanical study is not documented. It is feared that it will be eroded along with the loss of natural habitat and the extinction of medicinal plants, especially forest plants, due to excessive exploitation and land conversion. The younger generation's lack of interest in learning the knowledge of traditional medicine using plants can also make this traditional heritage slowly disappear. Ethnic groups in Lombok utilize various species of plants for traditional medicine by relying on their natural habitat. It is infrequent for forest plants with medicinal properties to be explicitly planted for cultivation. Apart from them yet accustomed to cultivating medicinal plants, there is a belief that they believe that cultivated medicinal plants do not have as good efficacy as those taken directly from nature [4-6]. Therefore, there is a need for ethnobotany studies for the community and the next generation in the use of plants to preserve customs in Sembalun Village, East Lombok Regency.

\section{RESEARCH METHODS}

This research was conducted in July 2020 at Sembalun Village, Sembalun District, East Lombok Regency. This type of research belongs to descriptive qualitative research using methods in data collection through surveys, observations, and review of documentation (documentation historical) and examines the facts that occur by describing descriptions of traditional plants used by the people of Sembalun Village. Field observations will be carried out directly by viewing and recording, 
interviewing, and documenting each object under study.

Data collection techniques in this study were interviews, observation, and documentation. Data from local community interviews was analyzed using a qualitative descriptive method that refers to interviews and various literature sources, with steps such as data reduction, data presentation, and concluding.

\section{RESULTS AND DISCUSSION}

Based on the research results conducted in Sembalun Village, interviews were conducted on 33 respondents, consisting of 20 men $(60.61 \%)$ and 13 women $(39.39 \%)$. Largely respondents are natives of the island of Lombok. Some of the respondents are trusted, namely people who know about traditional medicine (shamans, traditional birth attendants), village officials, community leaders, the general public who use medicinal plants. Respondents were divided into four age groups: adolescents aged 12-25 years, adults 26-45 years, elderly 46-65 years, and seniors $>65$ years (Ministry of Health of the Republic of Indonesia 2009). Most of the respondents $(63.64 \%)$ are $26-45$ years of adult age class. According to the Ministry of Health of the Republic of Indonesia (2009), the age range of 2645 years is a productive adult age class.

\section{Utilization of Plant Species for Medicinal Materials Plant}

Species used as medicine by the people of Sembalun Village are obtained from cultivation or self-planted either in their yards, gardens or grow wild around secondary forests and residential areas. The medicinal plants identified were 58 species of medicinal plants from 30 families. Ingredients Traditional medicinals that are processed are used directly or used as herbs with many benefits such as launching birth, shortness of breath, toothache, and external and internal diseases. Herbal ingredients are processed with various types of plants such as turmeric (Curcuma domestica), galangal (Languas galanga), temulawak (Curcuma xanthorrhiza), trembesi (barkSamanea saman), and other plant species. The people believe a total of 58 species of medicinal plants from 30 families of Sembalun to be able to cure 28 types of diseases such as high blood pressure, tuberculosis, fever medicine, control birth, as stamina, stomachache, toothache, tightness, acne, eye pain, burns, internal disease. , cancer, heart disease, body defense, an antidote to toxins and viruses, slimming facial treatments and skin diseases (Table 1).

Table 1. Species of Medicinal Plants Used by the Sembalun Village Community

\begin{tabular}{|c|c|c|c|}
\hline \multirow[b]{2}{*}{ No } & \multirow[t]{2}{*}{ Type of treatment } & \multicolumn{2}{|c|}{ Plant Species } \\
\hline & & Local & name Scientific name \\
\hline 1. & Anti-virus and disease in & Moringa & Moringa oleifera \\
\hline \multirow[t]{2}{*}{2.} & kidney stones & Binahong & Anredera cordifolia \\
\hline & & Kejibeling & Strobilanthes crispus \\
\hline \multirow[t]{2}{*}{3.} & Cough and tuberculosis & Mint & Mentha piperita \\
\hline & & lime & Citrusaurantifoli \\
\hline \multirow[t]{4}{*}{4.} & high Blood & Coffee Arabica & Coffea arabica \\
\hline & & robusta & Coffea robusta \\
\hline & & Singgapur & Muntingia calabura \\
\hline & & Bamboo & Dendrocalamus asper \\
\hline 5. & the smell of leather & Bluntas & Pluchea indica \\
\hline 6. & Chickenpox & Mango & Mangifera sp \\
\hline 7. & Diarrhea and dengue fever & Guava & Psidium guajava \\
\hline \multirow[t]{2}{*}{8.} & Drug skin & Asithaba / celery & Angelica \\
\hline & & Japanese & keiskeiKoidzumi \\
\hline 9. & Acne & thornSpinach & Amaranthus spinosus \\
\hline 10. & Cancer & Imperata & Imperata cylindrica \\
\hline 11. & Lesuh / flatulence & Garlic & Allium sativum \\
\hline \multirow[t]{4}{*}{12.} & outsideLuka & Jernat & Lantana camara \\
\hline & & Pumpkin / japan & Sechium edule \\
\hline & & orchid & Dendrobium $\mathrm{sp}$ \\
\hline & & Fir & $\begin{array}{l}\text { Casuarina } \\
\text { junghuhniana }\end{array}$ \\
\hline
\end{tabular}




\begin{tabular}{|c|c|c|c|}
\hline 13. & Launching the birth of & $\begin{array}{l}\text { Gegasingan } \\
\text { Temulawak } \\
\text { Kelapa gading } \\
\text { Lekok godek }\end{array}$ & $\begin{array}{l}\text { Sonneratia alba } \\
\text { Curcuma xanthorrhiza } \\
\text { Cocos nucifera var. } \\
\text { Eburnea } \\
\text { Piper betle }\end{array}$ \\
\hline $\begin{array}{l}14 . \\
15 .\end{array}$ & $\begin{array}{l}\text { Drug external wounds } \\
\text { fever }\end{array}$ & $\begin{array}{l}\text { red onion } \\
\text { Beringin } \\
\text { Ketujur } \\
\text { Mamangge } \\
\text { pomegranate } \\
\text { purslane } \\
\text { Bebele / grip }\end{array}$ & $\begin{array}{l}\text { Allium Cepa } \\
\text { Ficus benjamina } \\
\text { Sesbania grandiflora } \\
\text { Drymaria cordata } \\
\text { Punica granatum } \\
\text { PortulacaL } \\
\text { Centella binomial }\end{array}$ \\
\hline 16. & Disease in & $\begin{array}{l}\text { fig } \\
\text { Johar } \\
\text { Papaya }\end{array}$ & $\begin{array}{l}\text { Ficus racemosa } \\
\text { Cassia siamea } \\
\text { Carica papaya }\end{array}$ \\
\hline $\begin{array}{l}17 . \\
18 .\end{array}$ & $\begin{array}{l}\text { Slimming } \\
\text { an antidote to the poison }\end{array}$ & $\begin{array}{l}\text { Rambelang } \\
\text { Coconut }\end{array}$ & $\begin{array}{l}\text { Portulaca oleracea } \\
\text { Cocos nucifera }\end{array}$ \\
\hline 19. & Reducerhot and sore eyes & Banten & $\begin{array}{l}\text { Lannea } \\
\text { coromandelica }\end{array}$ \\
\hline 20. & skin diseases & $\begin{array}{l}\text { Andar lives } \\
\text { Jackfruit }\end{array}$ & $\begin{array}{l}\text { Anaphalis longifolia } \\
\text { Artocarpus } \\
\text { heterophyllus }\end{array}$ \\
\hline 21. & heart disease & $\begin{array}{l}\text { Fennel } \\
\text { Lemboke }\end{array}$ & $\begin{array}{l}\text { Foeniculum vulgare } \\
\text { Ficus septica }\end{array}$ \\
\hline 22. & eye drug & Carrot & Daucus carota \\
\hline 23. & Defensebody & $\begin{array}{l}\text { Litak } \\
\text { Ginger } \\
\text { Turmeric } \\
\text { whiteTurmeric } \\
\text { Laos / galangal } \\
\text { root of arc }\end{array}$ & $\begin{array}{l}\text { Alstonia scholaris } \\
\text { Zingiber officinale } \\
\text { Curcumadomestica } \\
\text { Curcumamanga } \\
\text { Languas galanga } \\
\text { Eurycoma longifolia }\end{array}$ \\
\hline 24. & Shortness of & $\begin{array}{l}\text { Banggle } \\
\text { Melaka }\end{array}$ & $\begin{array}{l}\text { Zingiber purpureum } \\
\text { Phyllanthus Emblica }\end{array}$ \\
\hline 25. & Toothache & $\begin{array}{l}\text { Bebalung adang } \\
\text { Rembige / widuri } \\
\text { Bandotan }\end{array}$ & $\begin{array}{l}\text { Euphorbia } \\
\text { pulcherrima } \\
\text { Calotropis gigantean } \\
\text { Ager atum conyzoides }\end{array}$ \\
\hline 26. & Stomach ache & $\begin{array}{l}\text { Asem } \\
\text { Katuk/sager }\end{array}$ & $\begin{array}{l}\text { Tamarindus indica } \\
\text { Sauropus } \\
\text { androgynous }\end{array}$ \\
\hline $\begin{array}{l}27 . \\
28 .\end{array}$ & $\begin{array}{l}\text { Wrong vein } \\
\text { All diseases }\end{array}$ & $\begin{array}{l}\text { Klembak } \\
\text { Mustajab/gadi }\end{array}$ & $\begin{array}{l}\text { Rheum officinale } \\
\text { Abelmoschus manihot } \\
\text { Medicinal }\end{array}$ \\
\hline
\end{tabular}

Plants are all species of medicinal plants known and believed to have medicinal properties. According to [7], medicinal plants can be grouped into traditional medicinal plants and modern medicinal plants, tested for their compounds and bioactive content. People in Sembalun Village still believe in medicinal plants, which are hereditary knowledge inherited from their ancestors and still used by the community.

Ashitaba (Angelica keiskei koidzumi) is one of the cultivated medicinal plants and is a plant originating from Japan. This plant is similar to the celery plant, so it is often called Japanese celery. In Indonesia, ashitaba plants can grow in East Lombok, located in Sembalun Village [8]. When cut, the stems, leaves, and tubers of the Ashitaba plant will release yellow sap from a group of flavonoid compounds called chalcone. According to research results [9], chalcone has two flavonoid compounds: xantoangeol and 4-hydrooxyricine. This compound has an active molecular structure and is a potent antioxidant that exceeds green tea and soybeans. The people of Sembalun Village use ashitaba sap as a medicine for various kinds of internal diseases and the leaves as a vegetable.

Betel (Piper betle) or the language of the Sembalun people, is called lekok, a plant native Indonesians that grows vines. This plant is often used as a medicinal plant and in traditional ceremonies. In a traditional ceremony, betel is 
pounded with areca nut and lime. The community believes this betel is a tooth reinforcement, so it is not easily brittle. Serih is also used to treat various diseases such as launching menstruation and is often mixed in herbal concoctions and is believed to launch childbirth by pregnant women. Betel contains essential oils in the form of betle phenol, sesquiterpenes, starch, attaches, sugar, tannins, and estragole [10]. In addition, this relative of the pepper plant also contains eugenol, kavikol, cadinene, kavikol, caryophyllene, cineole, and p-cymene. Sutomo (2009) added that leko also functions as a deodorizer, bad breath, strengthening teeth, treating canker sores, and bleeding gums. Eugenol contained in the leaves serves to prevent premature ejaculation, kill the fungus that causes vaginal discharge (Candida albicans), analgesic, and anesthetic. The tannins contained in the leaves function as astringent, liver protector, antidiarrheal, and antimutagenic [11].

Binahong (Anredera cordifolia) is a plant that is believed to have many benefits, such as headaches and kidney stones. This plant often grows both in the highlands and lowlands. The leaves of this plant are often used as herbal medicine. Binahong plants contain several active compounds such as flavonoids, alkaloids, terpenoids, and saponins. Binahong's ability to cure various types of diseases is closely related to the active compounds contained in it, such as flavonoids. Flavonoids can act directly as antibiotics with the interfering function of microorganisms such as bacteria and viruses [12]. This plant is often found in plantations and fields.

Mint (Mentha piperita) is one of the aromatic herbal plants producing essential oils. A distinctive aroma and has many properties, such as cough medicine and tuberculosis. This mint plant is also often used in the manufacture of toothpaste. Mentha piperita is a plant that produces peppermint oil. It contains menthol, menthone, methyl esters, and other active ingredients derived from monoterpenes: pulegone, piperitone menthofuran oil is Peppermint used in the bakery, chocolate and confectionery industries, tea processing, malt-containing foods and beverages, yarn spinning, pharmaceuticals, herbal medicine, soaps, and household cleaning agents including toothpaste, and cosmetics. Center for Statistics 2007 referred to in Personal 2010) [13]. This mint plant is easy to find in the yard community in Sembalun Village. Many use this plant because it is believed to have properties to treat coughs and tuberculosis.

\section{Utilization of Plant Species for Traditional Rituals Traditional}

Rituals are a hereditary tradition carried out by the people of Sembalun Village, such as ngeayuayu, sembe in the Bije Tawar ceremony use soyot plants in traditional rituals. The Sembalun Village community uses a total of 5 species of plants from 5 families for traditional rituals. Plant species are also used in several traditional ceremonies carried out by the people in Sembalun Village, such as betel leaf, areca nut, turmeric, and lime. The traditional rituals used by the community in Sembalun Village, namely at the Bale Loka traditional house, use soyot fruit as soap to wash the clothes of the stakeholders and residents who will traditionally enter the house. The clothes used when entering the traditional house should not be washed with soap chemicals. This tradition has been used for a, before knowing the existence of practical soap made from chemicals. However, this tradition is rarely carried out over time, only carried out by families of stakeholders who want to enter the house Bale Lokak traditional (Table 2).

Table 2. Plant Species for Indigenous Ritual Used by the Communities in Rural Sembalun

\begin{tabular}{|c|c|c|c|c|c|c|}
\hline No & $\begin{array}{l}\text { plant } \\
\text { species, }\end{array}$ & $\begin{array}{l}\text { scientific } \\
\text { name }\end{array}$ & $\begin{array}{c}\text { type } \\
\text { customary } \\
\text { ritual } \\
\end{array}$ & Family & $\begin{array}{c}\text { herbs used } \\
\text { Organs }\end{array}$ & takenSource \\
\hline 1. & Betel & Piper betle & $\begin{array}{l}\text { Sembe and } \\
\text { ngayu-ayu }\end{array}$ & Piperaceae & Leaf & $\begin{array}{c}\text { courtyard and } \\
\text { plantations }\end{array}$ \\
\hline 2. & Pinang & $\begin{array}{l}\text { Areca } \\
\text { catechu }\end{array}$ & $\begin{array}{l}\text { Sembeand } \\
\text { ngayu- ayu }\end{array}$ & Arecaceae & Fruit & Plantation \\
\hline 3. & Turmeric & $\begin{array}{l}\text { Curcuma } \\
\text { domestica }\end{array}$ & $\begin{array}{c}\text { ceremony Bije } \\
\text { bargaining }\end{array}$ & Zingiberaceae & rhizome & Perkarangan \\
\hline 4. & lime & $\begin{array}{c}\text { Citrus } \\
\text { aurantifolia }\end{array}$ & $\begin{array}{l}\text { ceremony Bije } \\
\text { bargaining }\end{array}$ & Rutaceae & Fruit & Perkarangan \\
\hline 5. & Soyot & $\begin{array}{l}\text { Sapindus } \\
\text { rarak }\end{array}$ & $\begin{array}{c}\text { tradition nyuci } \\
\text { traditional } \\
\text { clothes Bale } \\
\text { Lokak }\end{array}$ & Sapindaceae & seeds & Forest \\
\hline
\end{tabular}


Sembe is one of the traditional rituals that people often carry out in the village Sembalun used to treat various diseases and is also used in traditional rituals when going up to Mount Rinjani. This sembe is made from betel leaf, areca nut, and lime which is ground or chewed, which is then placed on the forehead and head of the person being treated. Sembe is also often used to prevent children from being disturbed by spirits. The liquid produced from the mixture of these plants is reddish.

Ngeayu-ayu is one of the traditional rituals of the people of Sembalun Village, an ancestral heritage that reflects gratitude and asks for safety. This traditional ritual is carried out every three years and has been passed down from generation to generation. In addition, the Ngayu Ayu ritual is a form of gratitude for the growth of red rice where this plant does not grow in place any. This ceremony also contains a symbol of a society that respects and loves nature. In this traditional ritual, the community also slaughters a black bull as a symbol of prosperity and then buries its head. According to ancient parents, the head of a buffalo buried in the ground was used as a stake [14].

The Ngayu-Ayu traditional ritual process lasts for two days. On the first day, water was collected from seven flowing springs that the people of Sembalun used. The water is left for one night in the houses of traditional leaders. The next day they were gathered together at the Traditional Cemetery, located to the west of the Sembalun Bumbung Field. The traditional ritual process is carried out in several stages, namely the diamond war symbolized as a war against the devil, which is carried out by throwing three times, namely the first throw by saying the fifth day, the second throwing by saying the 15 th, and the third throwing by saying the 25 th. The second stage is the arrow war poison, which the demon army did to take revenge when it lost in the diamond war. The demon army attacked the resident crops with poisoned arrows. In such a challenging atmosphere, there came a man named Raden Patra. The teacher gives instructions on dealing with attacks by using poison dart poison antidote in the form of water obtained from springs by Timba Bau. According to these instructions, the poison arrow war was finally ended by the people of the land of Sembalun, and gradually the plants in the rice fields returned to normal, and to commemorate this victory, a Bija Tawar ceremony was held.

The Bije Tawar ceremony or Bebija Tawar is a traditional procession system of the Sasak tribe, especially those in the Sembalun area, Sembalun District, East Lombok Regency, which begins with the Mait aiq ritual (taking water). The tradition of the Bebija Tawar ceremony is one of the ceremonies that are often carried out by the Sembalun community. This Bebija Tawar tradition is carried out when the rice season arrives because Bebija
Tawar aims to protect rice from pests or animals that want to disturb rice plants. This ceremony is carried out by surrounding the agricultural land with prayers, reading, and sprinkling. The solution used is made from a mixture of turmeric (Curcuma domestica) and lime (Citrus aurantifolia) which is then dissolved into Patara Guru water and water from 12 springs around Mount Rinjani. In addition, according to the mangku Patara Guru (the Stakeholder responsible for making 'Bije Tawar' and 'Sembe' solutions), this solution was also dipped in a stone which is said to be the first stone in Sembalun [14].

Soyot (Sapindus rarak) is a plant in the Sapindaceae family that the people of Sembalun Village use to replace soap. Before the existence of soap made from chemicals, the people of Sembalun used the seeds from the Soyot fruit to wash clothes and bathe. These seeds produced foam and were widely used by local people in ancient times. This fruit is still used by several traditional communities in Sembalun Village, one of which is the community or family of the Bale Lokak traditional householder. When entering a traditional house, stakeholders or the community should not use clothes carelessly, only use clothes that have never been washed with chemicals and only washed with soyot fruit. The stakeholder's family only carries out this tradition because of the times. Some traditional communities have used a lot of soap from chemicals.

\section{Parts of Plants Used by the Sembalun Village Community}

There are 12 parts of plants that are used by the Sembalun community for medicines and traditional rituals. The plant parts used are leaves, fruit, seeds, young leaves, stems, flowers, all parts, rhizomes, bark, tubers, roots, and sap. The most widely used plant parts are the leaves, as many as 21 species, and the least are the seeds and flowers of as much as 1 species. (Table $\mathbf{3}$ ).

The parts used consist of 12 groups of parts, namely fruit, leaves, young leaves, seeds, tubers, stems, flowers, whole parts, rhizomes, and bark, roots, and sap. The utilization of plant organs such as leaves is often used for medicine. According to, leaves are part of plant organs that are widely used as medicine because the leaves are generally soft and contain high water content (70\%-80\%) [15-16]. In addition, the leaves are a place of accumulation of photosynthate, which is thought to contain elements (organic substances) that have disease-curing properties. Substances that are abundant in the leaves are essential oils, phenols, potassium compounds, and chlorophyll. Other organs used are parts of the fruit that can be consumed directly or can be used as vegetables which are also believed to cure diseases. 
Table 1.3 Parts of Plants Used for Medicines

\begin{tabular}{ccccc}
\hline No & Parts of plants used & \multicolumn{2}{c}{$\begin{array}{c}\text { Number of plant species } \\
\text { used }\end{array}$} & Number of \\
\cline { 3 - 4 } & & $\begin{array}{c}\text { traditional } \\
\text { medicine }\end{array}$ & Ritual \\
& & 20 species & 1 species & 21 species \\
1. & Leaves & 6 species & 2 species & 8 species \\
2. & Fruit & 0 & 1 species & 1 species \\
3. & Seeds & 3 species & 0 & 3 species \\
4. & Young leaves & 2 species & 0 & 2 species \\
5. & Stem & 1 species & 0 & 1 species \\
6. & Flower & 2 species & 0 & 2 species \\
7. & Whole section & 5 species & 1 species & 6 species \\
8. & Rhizome & 6 species & 0 & 6 species \\
9. & Bark & 2 species & 0 & 2 species \\
10. & Tubers & 7 species & 0 & 7 species \\
11. & Root & 4 species & 0 & 4 species \\
12. & Sap & 58 species & 5 species & \\
\hline
\end{tabular}

The plant parts are processed into medicines that can be eaten directly or processed by cooking and pounding. Plants are cooked in various ways, including grilled, boiled, fried, and mixed with other ingredients [17-19]. The use of plant species for medicine is mainly processed through the pounding.

\section{CONCLUSION}

There are 58 species of medicinal plants from 30 families identified and 5 species of plants for traditional rituals from 5 families. Among them, namely temulawak (Curcuma xanthorrhiza), turmeric (Curcuma domestica), white turmeric (Curcuma mango), jae (Zingiber officinale), sekur (Kaempferia galanga), bangle (Zingiber purpureum), Ashitaba (Angelica keiskei koidzumi), Sirih (Piper). betle), mint (Mentha piperita), binahong (Anredera cordifolia), reeds (Imperata cylindrica), betel (Piper betle), areca nut (Areca catechu), lime (Citrus aurantifolia, turmeric (Curcuma domestica), soyot (Sapindus rarak). A total of 12 plant parts are used for medicines and traditional rituals. The most widely used plant parts are 21 species of leaves and 1 species of flowers and seeds.

\section{REFERENCES}

[1] Suryanto, S. (2018). Pemanfaatan Riset Biodiversitas Dalam Pendidikan Biologi Dan Pembentukan Karakter Peduli Lingkungandi Era Teknologi 4.0. Prosiding Seminar Nasional Biotik, 5 (1): 1-7.

[2] Noviar, D. (2016). Pengembangan Ensiklopedi Biologi Mobile Berbasis Android dalam Rangka Implementasi Kurikulum 2013. Cakrawala Pendidikan, (2): 198-207.

[3] Qamariah, N., Evi, M., \& Nurmila, D. (2018). Inventarisasi Tumbuhan Obat di Desa
Pelangsian Kecamatan Mentawa Baru Ketapang Kabupaten Kota Waringin Timur. Borneo Journal of Pharmacy, 1 (1): 1-10.

[4] Falah, F., Sayektiningsih, T., \& Noorcahyati, N. (2013). Keragaman jenis dan pemanfaatan tumbuhan berkhasiat obat oleh masyarakat sekitar Hutan Lindung Gunung Beratus, Kalimantan Timur. Jurnal Penelitian Hutan dan Konservasi Alam, 10(1), 1-18.

[5] Armanda, F. (2018). Identifikasi Tanaman Obat Di Kecamatan Talang Kelapa Dan Pemanfaatan Serta Sumbangsihnya Pada Mata Pelajaran Biologi. Bioilmi: Jurnal Pendidikan, 4(2), 7281.

[6] Yusro, F., Erianto, E., Hardiansyah, G., Mariani, Y., Aripin, A., Hendarto, H., \& Nurdwiansyah, D. (2021). Inventarisasi Tumbuhan Berkhasiat Obat di Hutan Kantuk Desa Paoh Benua Kabupaten Sintang. Jurnal Pijar Mipa, 16(2), 267-275.

[7] Utami, R. D., Zuhud, E. A., \& Hikmat, A. (2019). Medicinal Ethnobotany and Potential of Medicine Plants of Anak Rawa Ethnic at The Penyengat Village Sungai Apit Siak Riau. Media Konservasi, 24(1), 40-51.

[8] Sembiring, B. B., \& Manoi, F. (2011). Identifikasi mutu tanaman Ashitaba.

[9] Baba, H., Ohtsuka, Y., Haruna, H., Lee, T., Nagata, S., Maeda, M., ... \& Shimizu, T. (2009). Studies of anti-inflammatory effects of Rooibos tea in rats. Pediatrics International, 51(5), 700704.

[10] Hanum, N. A, Ismalayani, \& Maryam, S. (2012). Uji Efek Bahan Kumur Air Rebusan Daun Sirih (Piper betle L) terhadap Pertumbuhan Plak. Jurnal Kesehatan 1(10) : 1 -6 . 
[11]Hariana, A. (2008). Tumbuhan Obat dan Khasiatnya, Seri 2. Jakarta : Penebar Swadaya.

[12] Candra, L. M. M., Andayani, Y., \& Wirasisya, D. G. (2021). Pengaruh Metode Ekstraksi Terhadap Kandungan Fenolik Total dan Flavonoid Total Pada Ekstrak Etanol Buncis (Phaseolus vulgaris L.). Jurnal Pijar Mipa, 16(3), 397-405.

[13]Badan Pusat Statistik. (2018). Kecamatan Sembalun Dalam Angka 2018. Lombok Timur:Published.

[14] Riffani, A, S. (2016). Pemanfaatan Tumbuhan Pangan dan Obat Oleh Masyarakat Desa Sembalun Bumbung di Sekitar Taman Nasional Gunung Rinjani (Skripsi). Bogor: Institut Pertanian Bogor.

[15]Zaman, M., Saggar, S., Blennerhassett, J. D., \& Singh, J. (2009). Effect of urease and nitrification inhibitors on $\mathrm{N}$ transformation, gaseous emissions of ammonia and nitrous oxide, pasture yield and $\mathrm{N}$ uptake in grazed pasture system. Soil biology and biochemistry, 41(6), 1270-1280.

[16] Katiyar, C., Gupta, A., Kanjilal, S., \& Katiyar, S. (2012). Drug discovery from plant sources: An integrated approach. Ayu, 33(1), 10.

[17] Kusmana, C., \& Hikmat, A. (2015). Keanekaragaman hayati flora di Indonesia. Jurnal Pengelolaan Sumberdaya Alam dan Lingkungan (Journal of Natural Resources and Environmental Management), 5(2), 187-187.

[18] Oktafiani, R. (2018). Etnobotani tumbuhan obat pada masyarakat Desa Rahtawu di lereng Gunung Muria Kudus: sebagai sumber belajar mata kuliah Biologi tumbuhan obat berbentuk majalah (Doctoral dissertation, UIN Walisongo Semarang).

[19] Iskandar, J. (2017). Etnobiologi dan keragaman budaya di indonesia. Umbara, 1(1). 